\title{
PRODUCTION AND CHARACTERIZATION OF A THERMOSTABLE B- GLUCOSIDASE FROM Myceliophthora heterothallica
}

\author{
PRODUÇÃO E CARACTERIZAÇÃO DE UMA B-GLICOSIDASE TERMOESTÁVEL \\ $D E$ Myceliophthora heterothallica
}

\section{Maria Eduarda da Mata MARTINS ${ }^{1}$; Eduardo da Silva MARTINS ${ }^{2}$; Heytor Lemos MARTINS ${ }^{3}$}

1. Tecnóloga em Alimentos, Universidade do Estado de Minas Gerais, Frutal, MG, Brasil. 2. Professor, Doutor, Laboratório de Microbiologia, Departamento de Ciências Exatas e da Terra, Universidade do Estado de Minas Gerais, Frutal, MG, Brasil. 3. Mestrando em Ciências Ambientais, Universidade do Estado de Minas Gerais, Frutal, MG, Brasil.

\begin{abstract}
The conversion of biomass from agro-industrial residues into bioproducts is of great interest, especially to Brazil, where bioenergy has a huge potential for development. Enzymes involved in biodegradation of lignocellulosic biomass are those of the cellulase system, of which $\beta$-glucosidase is a constituent. The production and characterization of $\beta$-glucosidase by the thermophilic fungus Myceliophthora heterothallica by solid-state cultivation on different agro-industrial residues (sugarcane bagasse, sugarcane straw, wheat bran and a mixture of these three materials $(1: 1: 1 \mathrm{w} / \mathrm{w})$ was evaluated. Solid-state cultivation were conducted in $250 \mathrm{~mL}$ Erlenmeyer flasks, with $5 \mathrm{~g}$ of each substrate. Different culture parameters, such as supplementary nutrient solution to the substrate, supplementary nutrient solution $\mathrm{pH}$, initial substrate moisture and fungus incubation temperature, were evaluated to establish conditions of higher enzyme production by the fungus The greatest production of enzymes occurred in a mixture of wheat bran, sugarcane bagasse and straw bagasse (1:1:1). The activity of $\beta$-glucosidase was greater under the following conditions: nutrient solution composed of $\mathrm{NH}_{4} \mathrm{NO}_{3}, \mathrm{MgSO}_{4} .7 \mathrm{H}_{2} \mathrm{O}$ and $(\mathrm{NH} 4)_{2} \mathrm{SO}_{4}(0.1 \%)$, at $\mathrm{pH} 4.5$ or 6.0 , fungus incubation at $40^{\circ} \mathrm{C}$ or $45^{\circ} \mathrm{C}$, initial moisture of substrate at $80 \%$. Enzyme presented optimum $\mathrm{pH}$ at $\mathrm{pH} 5.0$ and good $\mathrm{pH}$ stability. Best temperature was $65^{\circ} \mathrm{C}$ and enzyme showed $100 \%$ stability for $1 \mathrm{~h}$, up to $60^{\circ} \mathrm{C}$. The use of agro-industrial residues provided good production of $\beta$-glucosidase by fungus, with enzyme having the characteristics desirable from the industrial application.
\end{abstract}

KEYWORDS: $\beta$-glucosidase. Fungus. Myceliophthora heterothallica. Solid-state cultivation.

\section{INTRODUCTION}

Solid-state cultivation (SSC) is an increasingly employed process to obtain microbial products for agricultural residues as substrates for microbial growth, with value aggregation (GAO et al., 2008; ASGHER et al., 2016). The application of residues to bioprocesses has become important from the environmental point of view since it reduces problems related to their inadequate management and consequent environmental damages. In addition, the materials' low cost and high availability make them excellent alternative substrates for obtaining microbial products used in industrial processes (PANDEY et al., 2000).

One of the most prominent sectors in Brazil, especially in the states of São Paulo and Minas Gerais, is the sugar-energy sector, due to the establishment and expansion of sugarcane plants in several municipalities (OLIVEIRA; MENDES, 2014). Since there is a great generation of sugar cane residues, such as straw and bagasse, the latter are potential substrates to obtain bioproducts.
Further, besides the use of biomass residues from sugarcane to generate electricity, industries produce second-generation ethanol with microbial enzymes derived from the residue, reported by scientific studies. However, obtaining fermentable sugars through the degradation of these materials may also enhance the production of several other industrial products, such as biosurfactants, flavoring agents, organic acids and others (SANTOS et al., 2012).

One of the most important groups of enzymes in the lignocellulosic biomass degradation is cellulases, an enzymatic complex whose enzymes act synergistically in the transformation of cellulose into monomers and glucose dimers. They are generally subdivided into three classes: endo-1,4- $\beta$ D-glucanases or endoglucanases (which break the glycosidic bonds of cellulose chains and create new terminals); exo-1,4- $\beta$-D-glucanases or cellobiohydrolases (responsible for terminal action leading to cellobiosis) and 1,4- $\beta$-D-glucosidases (which hydrolyze cellobiose to glucose) (YOON et al., 2014). 
$\beta$-Glucosidases increase the overall yield of fermentable sugars and reduce the inhibitory effect of cellobiose in other cellulolytic enzymes. Consequently, they continue the enzymatic hydrolysis process (RANI et al., 2014). These enzymes have several applications in industrial processes, including the conversion of glycosides from isoflavones to aglycones, which have antioxidant activities, and are more easily absorbed by the human intestine, providing such health benefits as the prevention of certain types of cancer and as risk-reduction factors against cardiovascular diseases, osteoporosis, menopausal symptoms and diabetes. In wine production, the addition of microbial $\beta$-glucosidase in vinification processes enhances the release of volatile terpenes (deglycosylated by the enzyme action) and contributes towards the wine's aromatic composition (SINGHANIA et al., 2013; SANTOS et al., 2016).

Thermophilic microorganisms have been studied to produce generally thermostable enzymes (MARTINS et al., 2013). Enzymatic mixtures used for the degradation of polysaccharides derived from biomass (cellulose, hemicellulose, pectin) are commonly produced by mesophilic fungal strains belonging to the genera Trichoderma and Aspergillus (VAN DEN BRINK; DE VRIES, 2011). However, thermophilic microorganisms are reported to contain enzymes which are more resistant to denaturation and proteolysis (KUMAR; NUSSINOV, 2001).

Enzyme thermal stability allow the saccharification of biomass polysaccharides at high temperatures and, consequently, decrease in reaction time, increase in greater mass transfer and the composition of substrate viscosity, which optimizes the processes in which they act, with decrease of costs. Thus, the alternative is the study of other microorganisms that produce thermostable enzymes that degrade plant biomass (BERKA et al., 2011; VAN DEN BRINK et al., 2013).

Myceliophthora is a genus composed of mesophilic and thermophilic fungi, which includes 10 species. $M$. thermophila, M. heterothallica, $M$. hinnulea and $M$. fergusii were described as thermophilic and regarded as industrially interesting enzyme producers due to their high activity and thermostability rates (MAIJALA et al., 2012). Current study evaluated $\beta$-glucosidase production by thermophilic fungus Myceliophthora heterothallica in solid-state cultivation using agroindustrial residues as substrates, to determine the effect of different fermentative parameters on enzyme production, and to characterize the enzyme in relation with optimal $\mathrm{pH}$ and temperature of performance and the stability to these factors.

\section{MATERIAL AND METHODS}

\section{Microorganism}

The thermophilic fungus Myceliophthora heterothallica F.2.1.4. was isolated from sugarcane bagasse compost provided by the Laboratory of Applied Biochemistry and Microbiology of the Universidade Estadual Paulista (UNESP), Brazil, and maintained in the Laboratory of Microbiology of the Universidade do Estado de Minas Gerais (UEMG), Brazil. The fungus was activated on Agar Malt medium (Acumedia) and incubated at $45^{\circ} \mathrm{C}$ for 5 days. Culture medium composed of oatmeal (Quaker) 3\% and bacteriological Agar 2\%, pH adjusted to 5.5, was kept under the same conditions of temperature and culture time for periodic peaks and conservation of pure culture.

\section{Enzyme production}

For each solid-state cultivation (SSC) culture, a pre-inoculum of the fungus was placed in a $250 \mathrm{~mL}$ Erlenmeyer flask containing $100 \mathrm{~mL}$ of a medium composed of oat flour (Quaker) 3\% and Agar (2\%), pH adjusted for 5.5 with $\mathrm{HCl}$. The fungus was inoculated onto the surface of this medium, by streaking, and incubated at $45^{\circ} \mathrm{C}$ until complete growth. The microorganism was then suspended with $150 \mathrm{ml}$ distilled water and inoculated into each Erlenmeyer.

The fungus was cultivated in $5.0 \mathrm{~g}$ of the following substrates: sugarcane bagasse, sugarcane straw, wheat bran and a mixture of these three materials $(1: 1: 1 \mathrm{w} / \mathrm{w})$ (namely MIX). Bagasse and sugarcane straw were retrieved from sugarcane plants in the municipality of Frutal MG Brazil. Wheat bran was purchased on the local market. Substrates were washed, dried at $60^{\circ} \mathrm{C}$ and sieved in a 10 mesh.

Solid-state cultivation cultures were conducted in $250 \mathrm{~mL}$ Erlenmeyer flasks, with $5 \mathrm{~g}$ of each substrate. In cultures for the evaluation of the influence of time on enzyme production, initially sterilized distilled water was used for hydration of the medium at $\mathrm{pH} 5.0$ and the fungus was cultured at $45^{\circ} \mathrm{C}$. Samples were taken every 24 hours, up to 240 hours (10 days). Further, $40 \mathrm{~mL}$ (wheat bran) and $80 \mathrm{~mL}$ (bagasse, cane straw and three-substrate mix) of distilled water were added to each sample. The mixture was homogenized manually and subsequently shaken $(50 \mathrm{rpm})$, for 20 minutes. The material was then filtered on a nylon cloth disc, centrifuged at $10000 \mathrm{xg}$ for $15 \mathrm{~min}$, at $5^{\circ} \mathrm{C}$, and the 
supernatant was used for the determination of enzymatic activities.

\section{Cultivation parameters}

Different culture parameters, such as supplementary nutrient solution to the substrate, supplementary nutrient solution $\mathrm{pH}$, initial substrate moisture and fungus incubation temperature, were evaluated to establish conditions of higher enzyme production by the fungus.

The following nutrient solutions were used on the substrate to assess the effect of substrate supplementation on enzyme production:

1 - Distilled water $0.1 \%$ (control);

2- $\mathrm{NH}_{4} \mathrm{NO}_{3}(0.1 \%)$;

3- $\left(\mathrm{NH}_{4}\right)_{2} \mathrm{SO}_{4}$;

4- $\mathrm{NH}_{4} \mathrm{NO}_{3}, \mathrm{MgSO}_{4} \cdot 7 \mathrm{H}_{2} \mathrm{O}$ and $\left(\mathrm{NH}_{4}\right)_{2} \mathrm{SO}_{4}(0.1 \%)$;

5- Yeast extract $(0.1 \%)$, so that the initial moisture is at $80 \%$. The $\mathrm{pH}$ rates of each solution were evaluated from 4.0 to 6.0 (with a variation of 0.5 in 0.5$)$, at a $5 \times 5$ factorial plan.

So that the effect of the substrate's initial moisture could be evaluated, volumes of the nutrient solution (chosen in the previous stage) were added to the inoculum so that initial moisture contents were $60 \%, 65 \%, 70 \%, 75 \%$ and $80 \%$. Fermentation temperatures evaluated were $40^{\circ} \mathrm{C}, 45^{\circ} \mathrm{C}, 50^{\circ} \mathrm{C}$ and $55^{\circ} \mathrm{C}$, at a $5 \times 5$ factorial plan.

\section{$\beta$-glucosidase characterization}

The effect of $\mathrm{pH}$ on the enzyme activity was evaluated at $\mathrm{pH}$ range between 3.0 and 10.0 using 0.1 M buffers: $\mathrm{pH}$ 3: sodium citrate; $\mathrm{pH}$ 3-5.5: sodium acetate; $\mathrm{pH}$ 6.0-6.5: MES; $\mathrm{pH}$ 7.0-7.5: HEPES; $\mathrm{pH}$ 8.0-10.0: glycine. Temperature effect was assayed by incubating the reaction mixture at a temperature ranging between 35 and $80^{\circ} \mathrm{C}$, in optimal $\mathrm{pH}$. Further, the effect of $\mathrm{pH}$ on enzyme stability was analyzed by incubating the crude enzyme solution in various buffers with $\mathrm{pH}$ ranging between 3.0 and 10.0 , during $24 \mathrm{~h}$, at $25^{\circ} \mathrm{C}$, followed by the determination of $\beta$-glucosidase residual activity, under optimum conditions of $\mathrm{pH}$ and temperature. Thermal stability was determined by incubating the crude enzyme between 40 and $80^{\circ} \mathrm{C}$, for $60 \mathrm{~min}$, followed by the determination of $\beta$ glucosidase residual activity, under optimum $\mathrm{pH}$ and temperature conditions.

Effect of glucose on $\beta$-glucosidase activity was determined by adding glucose at different concentrations $(0-50 \mathrm{mM})$ in the reaction mixture, under optimum $\mathrm{pH}$ and temperature conditions.
Enzymatic assay and statistical analysis of data

$\beta$-D-Glucosidase activity was assessed in a mixture of $50 \mathrm{~mm}$ sodium acetate buffer, $\mathrm{pH} 5.0$, $450 \mu \mathrm{L}$ of $4 \quad \mathrm{mM} \quad \mathrm{L}^{-1} \quad$ p-nitrophenyl- $\beta$-Dglucopyranoside (pNP-Glc) as substrate, and $50 \mu \mathrm{L}$ of the enzyme solution incubated for $10 \mathrm{~min}$, at $60^{\circ} \mathrm{C}$. Reaction ceased by adding $2 \mathrm{~mL}$ of $2 \mathrm{M}$ $\mathrm{Na}_{2} \mathrm{CO}_{3}$ and absorbance read at $410 \mathrm{~nm}$. One unit of $\beta$-glucosidase $(\mathrm{U})$ was defined as the amount of enzyme that releases $1 \mu \mathrm{mole}$ of nitrophenol/min in reaction conditions (PALMA-FERNANDEZ et al., 2002).

Analysis of variance of the experiments was carried out with data obtained from the different treatments applied. Scott-Knott test was applied at $5 \%$ significance.

\section{RESULTS AND DISCUSSION}

\section{Production of $\beta$-glucosidase by $M$. heterothallica on different substrates}

The highest production rate of initial $\beta$ glucosidase occurred in the substrate formed by the mixture of wheat bran, sugarcane bagasse and straw $(1: 1: 1 \mathrm{w} / \mathrm{w})$, with initial rates $\left(30.5 \mathrm{U} \mathrm{g}^{-1}\right)$ (Figure 1). Rates were high when compared to results in the literature, since no variation of cultivation parameters had yet been made for its production. As observed, prior to defining cultivation parameters that could increase $\beta$-glucosidase production, the activity rate obtained was close to some reports in the literature for fungal $\beta$-glucosidases, such as 40.4 $\mathrm{U} \mathrm{g}^{-1}$ obtained by $A$. fumigatus cultivated at $45^{\circ} \mathrm{C}$ in wheat bran (MORETTI et al., 2012), $41.8 \mathrm{U} \mathrm{g}^{-1}$ obtained by Thermomucor indicae-seudaticae N31 cultivated at $45^{\circ} \mathrm{C}$ in soybean meal (PEREIRA et al., 2015) and $30.5 \mathrm{U} \mathrm{g}^{-1}$ obtained by A. fumigatus cultivated at $45^{\circ} \mathrm{C}$ in sugarcane bagasse (DE OLIVEIRA RODRIGUES et al., 2017).

$\beta$-glucosidase activity was detected as from 2 days of culture, with peaks of activity on the $4^{\text {th }}$ and $7^{\text {th }}$ day, indicating that there may also be isoforms of the enzyme in the enzymatic extract. The peak of enzymatic activity occurred in 7 days, with rate presenting statistical difference when compared to the others. In the case of wheat bran, the activity was detected as from day 1 of cultivation, with peaks on the $6^{\text {th }}$ and $8^{\text {th }}$ day of culture. In sugarcane straw, it showed a peak between 2 and 5 days, and another between 7 and 10 days. In sugarcane bagasse, the enzymatic activity was also lower than that found in the other substrates (Figure 1). 
Results indicate that, in addition to complementing the wheat bran with carbon source and energy, sugarcane bagasse and straw may contribute towards a greater fungus growth (visual data, not quantified in the experiments). This may be due to the fact that the mixture provided a greater contact surface of the fungus to the substrates (SHI et al., 2009), particularly wheat bran which, in an isolated way, becomes more compacted and increases the enzymes production.

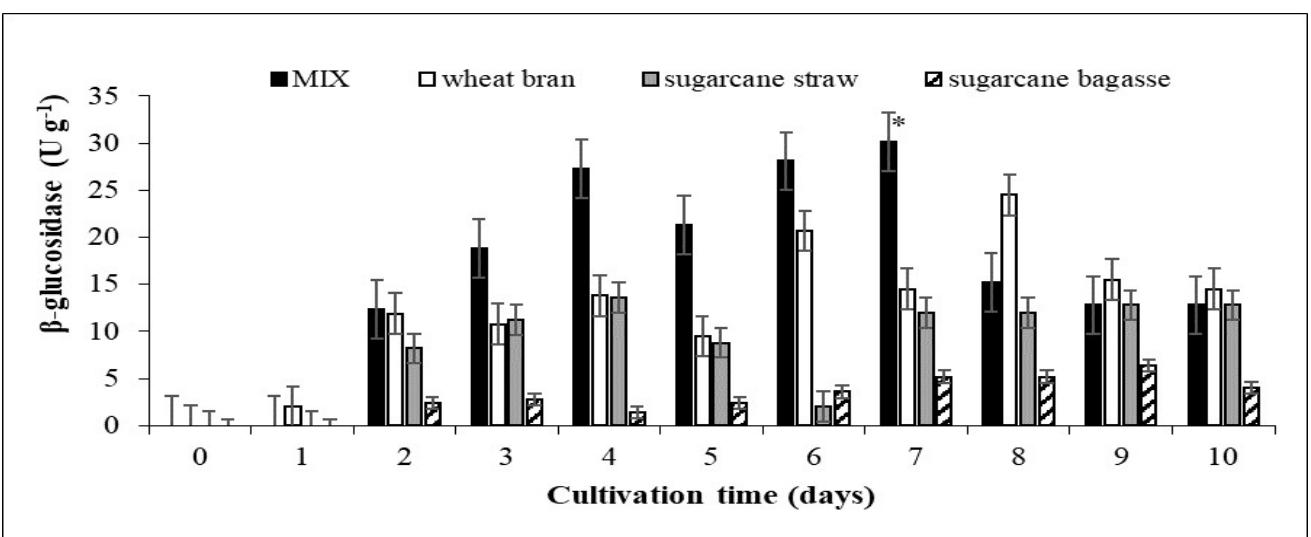

Figure 1. Production of $\beta$-glucosidase by $M$. heterothallica, on different substrates and culture times.

${ }^{*}$ Condition in which theres statistical difference in the Scott-Knott test $(<0.05)$.

Effect of culture parameters on $\beta$-glucosidase production by $M$. heterothallica

When the effect of different supplemental nutrient solutions to the substrate (MIX) on the $\beta$ glucosidase production was evaluated, it has been observed that the substrate supplementation increased enzyme production, when compared to control (water only). Statistical analysis of BG activity data with the different nutrient solutions revealed that the conditions in which there was a significant statistical difference comprised the supplementation of the substrate with the solution composed of $\mathrm{NH}_{4} \mathrm{NO}_{3}, \quad \mathrm{MgSO}_{4} .7 \mathrm{H}_{2} \mathrm{O}$ and $\left(\mathrm{NH}_{4}\right)_{2} \mathrm{SO}_{4}(0.1 \%)$, at $\mathrm{pH} 4.5$ and 6.0 (Figure 2). When compared to initial rates in control, the supplementation with the solution increased by almost 3 times the maximum $\beta$-glucosidase activity rate obtained by the fungus (Figure 2). The above demonstrated the importance of evaluating this factor for enzyme production.

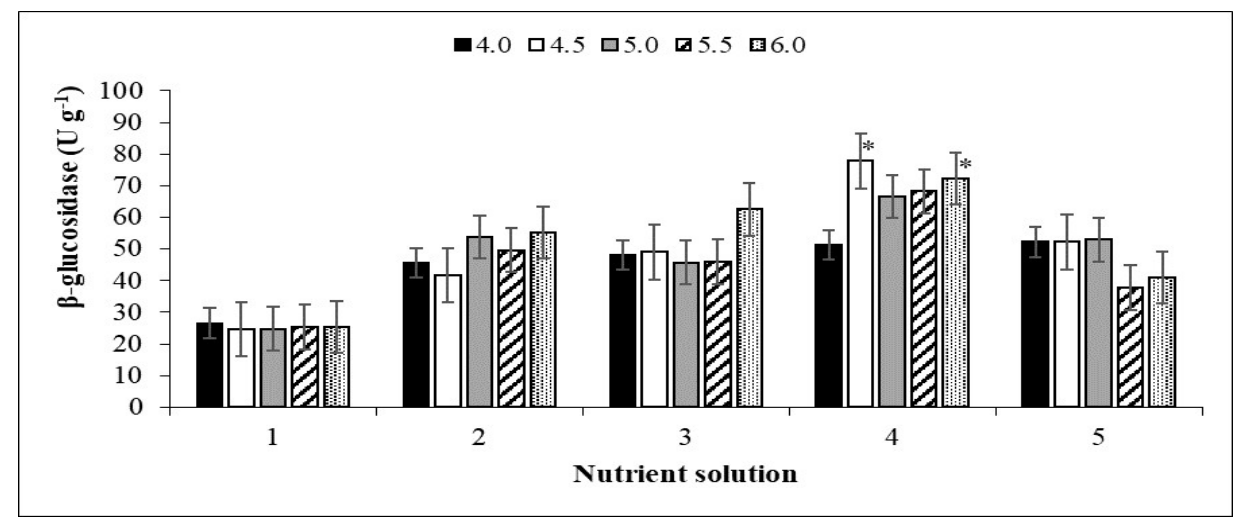

Figure 2. Production of $\beta$-glucosidase by $M$. heterothallica in substrate composed by wheat bran, sugarcane bagasse and sugarcane straw (1:1:1), supplemented with different nutrient solutions at different $\mathrm{pH}$ values, in 4 days of cultivation. 1- Distilled water (control); 2- $\mathrm{NH}_{4} \mathrm{NO}_{3}(0.1 \%)$; 3- $\left(\mathrm{NH}_{4}\right)_{2} \mathrm{SO}_{4}$ $(0.1 \%) ; 4-\mathrm{NH}_{4} \mathrm{NO}_{3}, \mathrm{MgSO}_{4} .7 \mathrm{H}_{2} \mathrm{O}$ and $\left(\mathrm{NH}_{4}\right)_{2} \mathrm{SO}_{4}(0.1 \%) ; 5$ - yeast extract $(0.1 \%)$.

*Conditions in which there was statistical difference in the Scott-Knott test $(<0.05)$.

As a rule, when studying complementary source of nutrients to the substrate, nitrogen sources are mainly evaluated. Gottschalk et al. (2013) reported that inorganic nitrogen sources are generally more easily assimilated by fungi than organic ones, even though they point out that this depends on fungal lineage, the nature of the element and its concentration. Ahmed et al. (2017) cited that most research works on the microbial $\beta$ - 
glucosidase production do not focus on the optimization of supplementary nitrogen sources to the carbon sources in the fermentation. The authors also reinforce the need to study the mechanisms by which nitrogen sources influence the expression of these enzymes. These observations corroborate the importance of the evaluation of different supplementary sources of nutrients on $\beta$-glucosidase production.

In the case of the substrate's initial $\mathrm{pH}$, different species require different $\mathrm{pH}$ rates for optimal $\beta$-glucosidase production. However, as in the case of temperature, most $\beta$-glucosidases research fails to report $\mathrm{pH}$ optimization for its production. A random $\mathrm{pH}$ rate is used in which these species grow optimally (AHMED et al., 2017). This information reinforces the study of these variables in current analysis. Throughout the microbial culture, in solid-state fermentation, $\mathrm{pH}$ rate is not controlled because of the process's heterogeneity (GARCIA et al.,
2015). According to Pandey et al. (2000), the difficulty of monitoring and controlling parameters in solid-state fermentation is perhaps the main disadvantage of the process, and $\mathrm{pH}$ variations during the fermentation process may occur due to the metabolic activity of the microorganisms. They may be increased or decreased according to the by-products released or the nutrients consumed during the process.

Under the best conditions established in previous experiments, the effect of the initial moisture of the substrate (MIX) and the incubation temperature of the fungus on $\beta$ glucosidase production was determined. Incubation of the fungus at $40^{\circ} \mathrm{C}$ or $45^{\circ} \mathrm{C}$, with initial substrate moisture at $80 \%$, provided the highest activity of the enzyme, with significant statistical difference. Higher moisture rates $(85 \%)$ decreased enzymatic activity at all incubation temperatures (Figure 3).

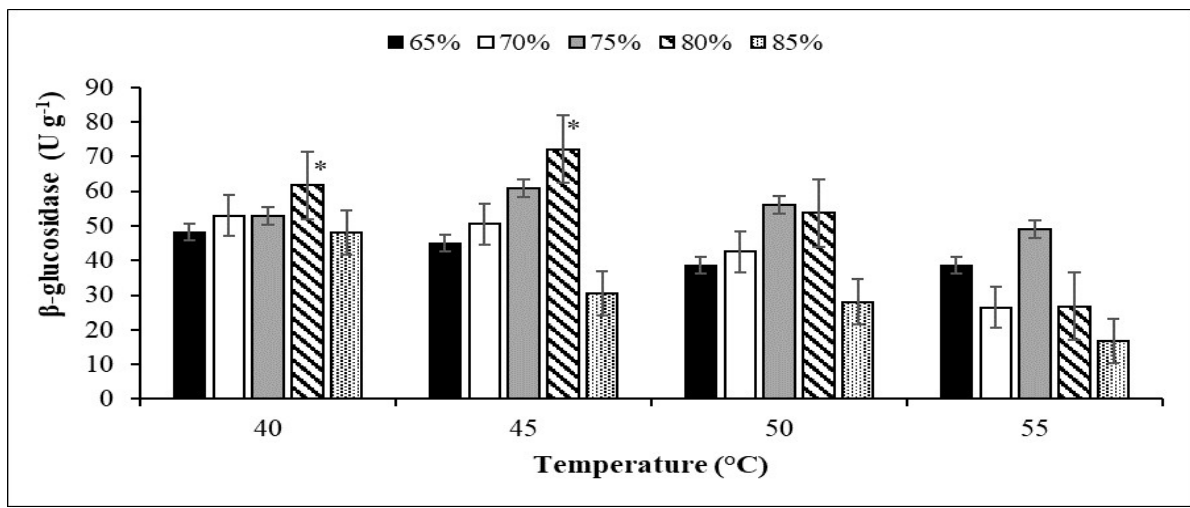

Figure 3. Production of $\beta$-glucosidase by $M$. heterothallica in substrate composed by wheat bran, sugarcane bagasse and sugarcane straw $(1: 1: 1)$, supplemented with $\mathrm{NH}_{4} \mathrm{NO}_{3}, \mathrm{MgSO}_{4} \cdot 7 \mathrm{H}_{2} \mathrm{O}$ and $\left(\mathrm{NH}_{4}\right)_{2} \mathrm{SO}_{4}$ $(0.1 \%)$, at $\mathrm{pH} 4.5$, in 4 days of cultivation, at different conditions of moisture and fungus incubation temperature.

*Conditions in which there was statistical difference in the Scott-Knott test $(<0.05)$.

Regarding to substrate moisture, when the moisture content is below the required level, the nutrients' solubility is limited and hinders their effective absorption by the fungi. On the other hand, when it is raised, the substrate particles are surrounded by a thick layer of water, tending to stick together and limiting gas exchanges. Thus, it is essential to establish the adequate level of moisture for microbial growth and obtain its products (YOON et al., 2004; SANTOS et al., 2016).

Cultivation temperature for the production of $\beta$-glucosidases varies from species to species. In most cases, it coincides with the optimal temperature of growth of the microorganism. On the other hand, the ideal temperature for enzyme production does not always correspond to the temperature of the microorganism's natural habitat (AHMED et al., 2017). Consequently, several microorganisms produce the enzyme at temperatures other than its optimum growth, as occurred in current assay with $M$. heterothallica fungus, where optimum growth temperature was between $45^{\circ} \mathrm{C}$ and $50^{\circ} \mathrm{C}$, although the highest enzymatic activity rate was detected when the cultivation occurred at $40^{\circ} \mathrm{C}$. Elyas et al. (2010) reported that the optimal growth temperature of 
Aspergillus AS58 fungal strain was $30^{\circ} \mathrm{C}$, whereas the highest activity rate of its $\beta$-glucosidase was detected at $35^{\circ} \mathrm{C}$.

High or very low temperatures may decrease the microorganism's growth and thus the formation of the product. Low thermal conductivity of the agro-industrial residues used in solid-state cultivation processes may hinder the dissipation of the metabolic heat generated by microbial growth (PANDEY et al., 2003). Thus, the analysis of culture temperature is highly relevant for delineating a bioprocess to produce enzymes (SANTOS et al., 2016).

\section{Biochemical characterization of $\beta$-glucosidase}

$\beta$-glucosidase produced has a better performance at $\mathrm{pH}$ rates between 4.0 and 5.5, with activities very close to each other at this $\mathrm{pH}$ range, with a peak at $\mathrm{pH} 5.0$ when incubated at $60^{\circ} \mathrm{C}$
(Figure 4). No enzymatic activity occurred at $\mathrm{pH}$ rates above 7.5. Thus, data indicate that the fungus produces a $\beta$-glucosidase that may be applied in processes that require higher acidic $\mathrm{pH}$ rates. Acid cellulase is more adequate to degrade feedstock cellulose in the bioconversion industry, where biomass undergoes acid pre-treatment. The ability to work in an acidic $\mathrm{pH}$ environment is also a requirement for enzymes used in the textile industry in the finishing step where they act on cellulolytic fibers (SHARMA et al., 2016).

With respect to stability when exposed for $24 \mathrm{~h}$ in the absence of substrate in buffers with different $\mathrm{pH}$ rates, it has been observed that the enzyme maintains more than $80 \%$ of its activity within a wide $\mathrm{pH}$ range (3.5 to 9.5). At optimum $\mathrm{pH}$ (5.0), it maintained $88.1 \%$ of its activity, after $24 \mathrm{~h}$ (Figure 4).

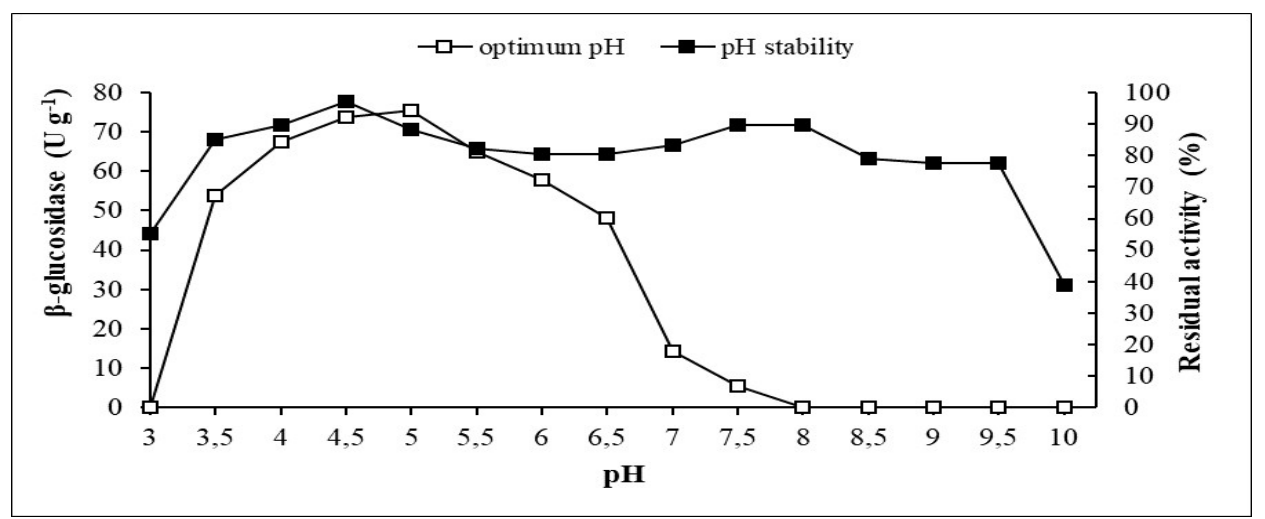

Figure 4. Biochemical characterization of $\beta$-glucosidase produced by $M$. heterothallica.

- optimum $\mathrm{pH}$; - $\square$-pH stability for $24 \mathrm{~h}$, a $25^{\circ} \mathrm{C}$.

According to Baffi et al. (2011), most microbial $\beta$-glucosidases present optimum $\mathrm{pH}$ between 4.0 and 6.0. Garcia et al. (2015) reported that optimal $\mathrm{pH}$ of $\beta$-glucosidase produced by Lichtheimia ramosa ranged between 5.0 and 6.0 , with peak at $\mathrm{pH}$ 5.5. With regard to $\mathrm{pH}$ stability, the enzyme also showed high stability (over 90\%) over a wide $\mathrm{pH}$ range (between 3.0 and 10.0), similar to results in current assay. Santa-Rosa et al. (2018) reported that $\beta$-glucosidase from Penicillium sp. presented a higher activity at $\mathrm{pH}$ rates between 5.0 and 7.0, with optimum activity at $\mathrm{pH} 6.0$.

In the case of optimum temperature for $\beta$ glucosidase activity, an increase in enzyme activity was observed up to $65^{\circ} \mathrm{C}$, at which temperature (75.4 $\mathrm{U} \mathrm{g} \mathrm{g}^{-1}$ ) was detected. Activity decreases as from this temperature, especially after $75^{\circ} \mathrm{C}$ (Figure $5)$. In the case of the enzyme's thermostability, results showed that $\beta$-glucosidase presented $100.0 \%$ and $48.6 \%$ stability when respectively exposed at $60^{\circ} \mathrm{C}$ and $65^{\circ} \mathrm{C}$. Activity declined in temperatures above $65^{\circ} \mathrm{C}$. Enzyme was not detected when exposed at $70^{\circ} \mathrm{C}$, for $1 \mathrm{~h}$ (Figure 5). Pereira et al. (2015) reported that $\beta$-glucosidase from Myceliophthora thermophila presented optimum activity at $70^{\circ} \mathrm{C}$ and the enzyme maintained more than $93 \%$ of its original activity when incubated at $55^{\circ} \mathrm{C}$.

Optimal $\beta$-glucosidase temperature of fungus $M$. heterothallica lies within the optimum temperature range of these enzymes produced by different fungi. Results demonstrate that enzyme has a significant thermostability when compared to enzymes of several microorganisms reported in the literature. Many commercial $\beta$-glucosidases of fungi are stable for a short time at high temperatures, denaturing at higher temperatures or time of exposure (LIU et al., 2012). Although enzymes from different organisms vary greatly in properties and functions, cost-effective production, high hydrolytic efficiency and great tolerance to unfavorable conditions are prerequisites of an industrial 
biocatalyst in various applications. Of particular interest, $\beta$-glucosidases from thermophilic fungi are more favorable due to the high-temperature activity and good thermostability (PEI et al., 2011; MALLEK-FAKHFAKH et al., 2016).

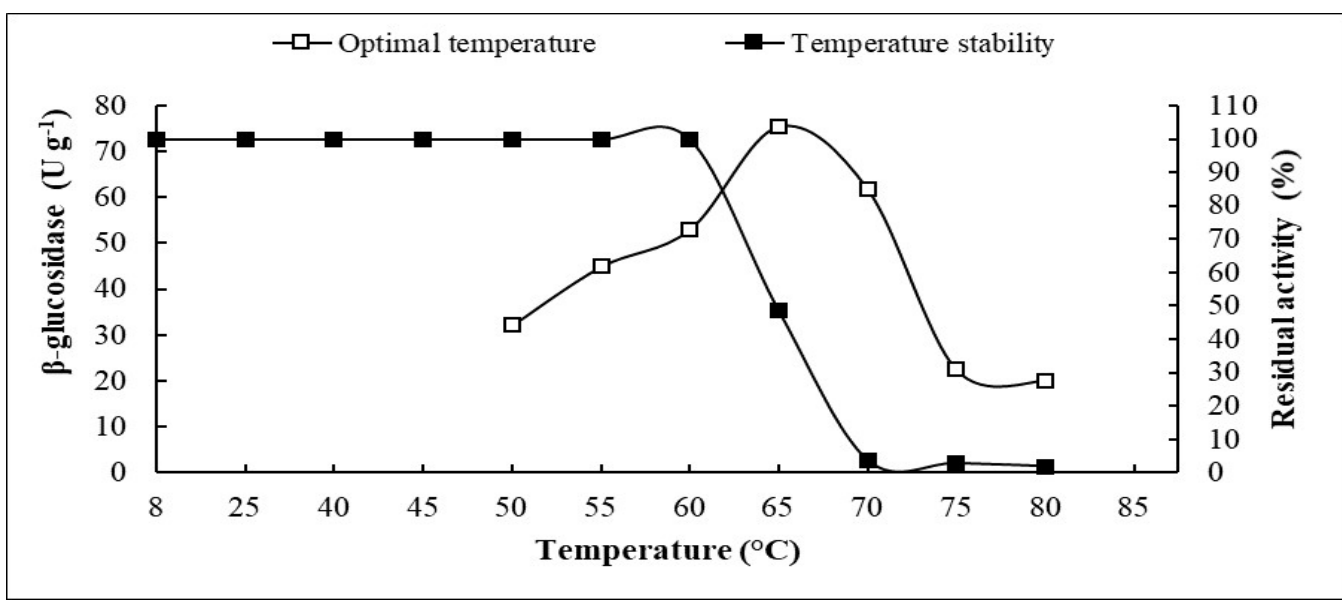

Figure 5. Biochemical characterization of $\beta$-glucosidase produced by M. heterothallica .

- optimum temperature; $-\square$ - temperature stability for $1 \mathrm{~h}$.

Thermostability study showed that $\beta$ glucosidase from $M$. heterothallica is highly thermostable as it retained above $90 \%$ of its original activity after $120 \mathrm{~min}$ of incubation up to $60^{\circ} \mathrm{C}$. At $65^{\circ} \mathrm{C}$, enzyme half-life was approximately $1 \mathrm{~h}$. (Figure 6).

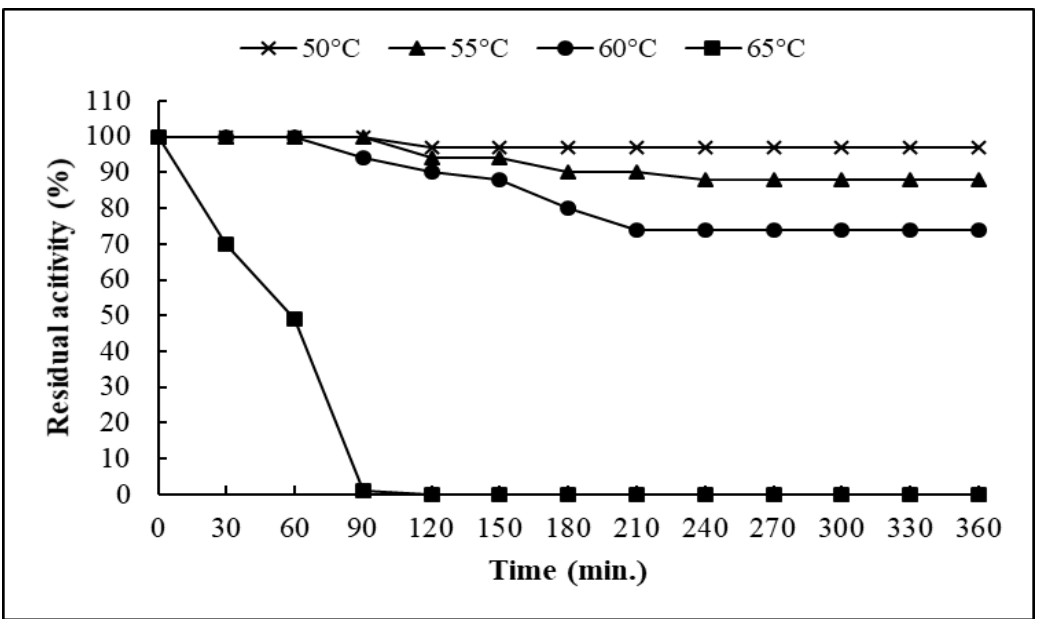

Figure 6. Effect of different temperatures on $\beta$-glucosidase stability.

Pereira et al. (2015) reported the production of a $\beta$-glucosidase of the thermophilic fungus Thermoascus aurantiacus, which showed maximum activity within $70^{\circ} \mathrm{C}$ and $75^{\circ} \mathrm{C}$ range. It maintained $75 \%$ stability when incubated for $1 \mathrm{~h}$ at temperatures between $55^{\circ} \mathrm{C}$ and $75^{\circ} \mathrm{C}$. Garcia et al. (2015) reported a $\beta$-glucosidase of the mesophilic fungus Lichtheimia ramosa, which presented optimum temperature of $65^{\circ} \mathrm{C}$, maintaining $98 \%$ and $40 \%$ of its activity when exposed for $1 \mathrm{~h}$ at $55^{\circ} \mathrm{C}$ and $60^{\circ} \mathrm{C}$, respectively. Santa-Rosa et al. (2018) reported the production of a $\beta$-glucosidase of Penicillium sp., with an optimal temperature of $60^{\circ} \mathrm{C}$, maintaining $95.7 \%$ of its activity when incubated for $1 \mathrm{~h}$.
The high thermostability of $\beta$-glucosidase of $M$. heterothallica presented in the present work is desirable in industrial processes that require cellulolytic enzymes that maintain activity under high temperatures.

Glucose in the reaction medium caused a decrease in $\beta$-glucosidase activity with increasing glucose concentration. Residual activity of the enzyme at concentrations $5,10,15$, and $20 \mathrm{mM}$ was $66.3 \%, 54.6 \%, 43.0 \%$, and $29.3 \%$, respectively. It actually decreased progressively, maintaining $4.0 \%$ of activity with glucose at $40 \mathrm{mM}$ (Fig 7). In order to verify whether the inhibition of the enzyme was competitive or not, a test was performed in which the substrate concentration was increased from 
$4 \mathrm{mM}$ to $10 \mathrm{mM}$. Since enzymatic activity returned to the level as when the reaction medium had no glucose (100\% of original activity), inhibition proved to be competitive.

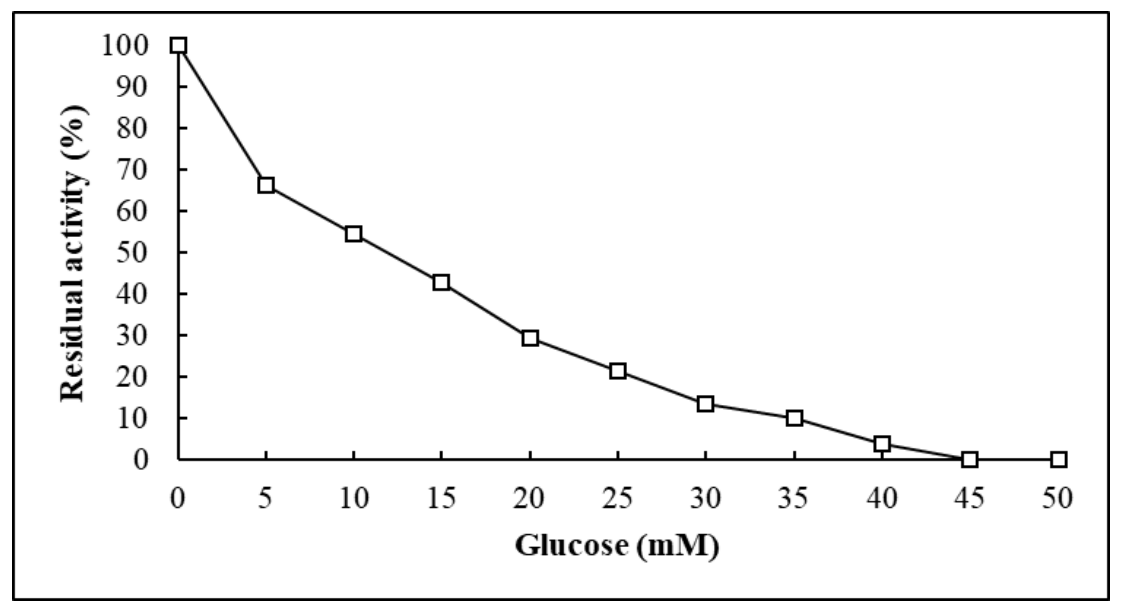

Figure 7: Effect of glucose on $\beta$-glucosidase activity by $M$. heterothallica.

Since most microbial $\beta$-glucosidases are inhibited by glucose, it becomes a major limitation for the use of these enzymes in industrial processes (LEITE et al., 2008). High glucose concentrations may directly or indirectly interfere with the binding of the substrate to the activated site and reduce the reaction rate (SINGHANIA et al., 2013). Inhibition of $\beta$-glucosidase produced by $M$. heterothallica was completely reversed when the substrate concentration increased but maintained the same glucose concentration. Results demonstrated that enzyme interaction with the inhibitor was competitive. Competitive inhibition may be reversed by increasing the concentration of the substrate. The reversibility of glucose inhibition of $\beta$-glucosidase in current study confirmed the potential of the enzyme in applications requiring saccharification processes.

\section{CONCLUSIONS}

The use of agro-industrial residues as substrate provided good $\beta$-glucosidase production by $M$. heterothallica, with the enzyme having the desirable characteristics from industrial application, such as good thermostability and stability over a wide $\mathrm{pH}$ range.

The high thermostability of $\beta$-glucosidase of $M$. heterothallica presented in the present work is desirable in industrial processes that require cellulolytic enzymes that maintain activity under high temperatures.

\section{ACKNOWLEDGMENTS}

The authors wish to thank Programa PIBIC/UEMG for financial support.

RESUMO: A conversão da biomassa vegetal proveniente de resíduos agroindustriais em bioprodutos é de grande interesse, principalmente para o Brasil, onde a agroenergia possui grande potencial de desenvolvimento. Enzimas envolvidas na biodegradação da biomassa lignocelulósica fazem parte do grupo das celulases, no qual a $\beta$-glucosidase é um constituinte. O presente estudo avaliou a produção e caracterização de uma $\beta$-glicosidase pelo fungo termofílico Myceliophthora heterothallica por cultivo em estado sólido de diferentes resíduos agroindustriais (bagaço de cana-de-açúcar, palha de cana-de-açúcar, farelo de trigo e em uma mistura dos três materiais (1:1: $1 \mathrm{p} / \mathrm{p})$. O cultivo em estado sólido foi realizado em frascos Erlenmeyer de $250 \mathrm{~mL}$, contendo $5 \mathrm{~g}$ de cada substrato. Diferentes parâmetros de cultivo, como solução nutriente suplementar ao substrato, $\mathrm{pH}$ da solução nutriente suplementar, umidade inicial do substrato e temperatura de incubação do fungo foram avaliados, visando estabelecer condições para maior produção da enzima pelo fungo. A maior produção da enzima ocorreu na mistura de farelo de trigo, e bagaço e palha de cana-de-açúcar $(1: 1: 1)$. A atividade da $\beta$-glicosidase foi maior nas seguintes condições: solução nutriente composta por $\mathrm{NH}_{4} \mathrm{NO}_{3}$, $\mathrm{MgSO}_{4} \cdot 7 \mathrm{H}_{2} \mathrm{O}$ e $\left(\mathrm{NH}_{4}\right)_{2} \mathrm{SO}_{4}(0,1 \%) \mathrm{com} \mathrm{pH} 4,5$ e 6,0 , temperatura de incubação do fungo a $40^{\circ} \mathrm{C}$ e $45^{\circ} \mathrm{C}$, com umidade inicial do substrato em $80 \%$. A enzima apresentou $\mathrm{pH}$ ótimo de 5,0, e boa estabilidade ao $\mathrm{pH}$. A temperatura ótima foi de $65^{\circ} \mathrm{C}$, e a enzima apresentou $100 \%$ de estabilidade por $1 \mathrm{~h}$, até $60^{\circ} \mathrm{C}$. A utilização de 
resíduos agroindustriais proporcionou boa produção de $\beta$-glicosidase pelo fungo, com a enzima apresentando características desejáveis para aplicação industrial.

PALAVRAS-CHAVE: Enzimas celulolíticas. Fungo. Myceliophthora heterothallica. Cultivo em estado sólido.

\section{REFERENCES}

AHMED, A.; NASIN, F. U.; BATOOL, K.; BIBI, A. Microbial $\beta$-glucosidase: sources, production and applications. J Appl Environ Microbiol, v. 5, n. 1, p. 31-46, 2017.

ASGHER, M.; KHAN, S. W.; BILAL, M. Optimization of lignocellulolytic enzyme production by Pleurotus eryngii WC 888 utilizing agro-industrial residues and bio-ethanol production. Rom Biotechnol Lett, v. $21, \mathrm{n}$. 1, p. 11133-11143, 2016.

BAFFI, M. A.; TOBAL, T. M.; HENRIQUE, J.; LAGO, G.; LEITE, R. S. R.; BOSCOLO, M.; GOMES, E.; DA SILVA, R. A novel $\beta$-glucosidase from Sporidiobolus pararoseus: characterization and application in winemaking. J Food Sci., v. 76, n.7, p. 997-1002, 2011. https://doi.org/10.1111/j.1750-3841.2011.02293.x

BERKA, R. M.; GRIGORIEV, I. V.; OTILLAR, R.; SALAMOV, A.; GRIMWOOD, J.; REID, I.; ISHMAEL, N.; JOHN, T.; DARMOND, C.; MOISAN, M. C.; HENRISSAT, B.; COUTINHO, P. M.; LOMBARD, V.; NATVIG, D. O.; LINDQUIST, E.; SCHMUTZ, J.; LUCAS, S.; HARRIS, P.; POWLOWSKI, J.; BELLEMARE, A.; TAYLOR, D.; BUTLER, G.; DE VRIES, R. P.; ALLIJN, I. E.; VAN DEN BRINK, J.; USHINSKY, S.; STORMS, R.; POWELL, A. J.; PAULSEN, I. T.; ELBOURNE, L. D.; AKER, S. E.; MAGNUSON, J.; LABOISSIERE, S.; CLUTTERBUCK, A. J.; MARTINEZ, D.; WOGULIS, M.; DE LEON, A. L.; REY, M. W.; TSANG, A Comparative genomic analysis of the thermophilic biomass-degrading fungi Myceliophthora thermophila and Thielavia terrestris. Nat Biotechnol, v. 29, n. 10, p.922-927, 2011. https://doi.org/10.2172/1165279

DE OLIVEIRA RODRIGUES, P.; PEREIRA, J. C.; QUEIROZ, D.; GURGEL, L. V. A.; PASQUINI, D.; BAFFI, M. A. Synergistic action of an Aspergillus (hemi-) cellulolytic consortium on sugarcane bagasse saccharification. Indl Crops Prod, v. 109, n. 1, p. 173-181, 2017.

https://doi.org/10.1016/j.indcrop.2017.08.031

ELYAS, K. K.; MATHEW, A.; SUKUMARAN, R. K.; ALI, P. P.; SAPNA, K.; KUMAR, S. R.; MOL, K. R. Production optimization and properties of beta glucosidases from a marine fungus Aspergillus SA 58. New Biotechnol, v. 27, n. 4, p. 347-351, 2010. https://doi.org/10.1016/j.nbt.2010.02.007

GAO, J.; WENG, H.; ZHU, D.; YUAN, M.; GUAN, F.; XI, Y. Production and characterization of cellulolytic enzymes from the thermoacidophlilic fungal Aspergillus terreus M11 under solid-state cultivation of corn stover. Bioresour Technol, v. 99, n. 16, p. 7623- 7629, 2008. https://doi.org/10.1016/j.biortech.2008.02.005

GARCIA, N. F. L.; SANTOS, F. R. S.; GONÇALVES, F. A.; DA PAZ, M. F.; FONSECA, G. G.; LEITE, R. S. R. Production of $\beta$-glucosidase on solid-state fermentation by Lichtheimia ramosa in agro-industrial residues: Characterization and catalytic properties of the enzymatic extract. Electron J Biotechnol, v. 18, n. 4, p. 314-319, 2015. https://doi.org/10.1016/j.ejbt.2015.05.007

GOTTSCHALK, L. M. F.; PAREDES, R. D. S.; TEIXEIRA, R. S. S.; SILVA, A. S. A D.; BON, E. P. D. S. Efficient production of lignocellulolytic enzymes xylanase, $\beta$-xylosidase, ferulic acid esterase and $\beta$ glucosidase by the mutant strain Aspergillus awamori 2B.361 U2/1. Braz J Microbiol, v. 44, n. 2, p. 569-576, 2013. https://doi.org/10.1590/S1517-83822013000200037

KUMAR, S.; NUSSINOV, R. How do thermophilicproteins deal with heat? A review. Cell. Mol. Life Sci., v. 58, n. 9, p. 1216-1233, 2001. https://doi.org/10.1007/PL00000935 
LEITE, R. S. R.; ALVES-PRADO, H. F.; ABRAL, H.; PAGNOCCA, F. C.; GOMES, E.; DA SILVA, R. Production and characteristics comparison of crude $\beta$-glucosidases produced by microorganisms Thermoascus aurantiacus e Aureobasidium pullulans in agricultural wastes. Enzyme Microb Technol, v. 43, p. 391-395, 2008. https://doi.org/10.1016/j.enzmictec.2008.07.006

LIU, D.; ZHANG, R.; YANG, X.; ZHANG, Z.; SONG, S.; MIAO, T.; SHEN, Q. Characterization of a thermostable $\beta$-glucosidase from Aspergillus fumigatus Z5, and its functional expression in Pichia pastoris X33. Microb Cell Fact, v. 11, n. 25, p. 1-15, 2012. https://doi.org/10.1186/1475-2859-11-25

MAIJALA, P.; KANGO, N.; SZIJARTO, N.; VIIKARI, L. Characterization of hemicellulases from thermophilic fungi. Antonie Leeuwenhoek, v. 101, n. 4, p. 905-917, 2012. https://doi.org/10.1007/s10482012-9706-2

MALLEK-FAKHFAKH, H.; BELGHITH, H. Physicochemical properties of thermotolerant extracellular $\beta$ glucosidase from Talaromyces thermophiles and enzymatic synthesis of cello-oligosaccharides. Carbohydr Res, v. 419, n. 1, p. 41-50, 2016. https://doi.org/10.1016/j.carres.2015.10.014

MARTINS, E. S.; LEITE, R. S. R.; DA SILVA, R.; GOMES, E. Purification and properties of polygalacturonase produced by thermophilic fungus Thermoascus aurantiacus CBMAI756 on solid-state fermentation. Enzyme Res, v. 2013, n. 2013, p. 1-7, 2013. https://doi.org/10.1155/2013/438645

MORETTI, M. M. S.; BOCCHINI-MARTINS, D. A.; DA SILVA, R.; RODRIGUES, A.; SETTE, L. D.; GOMES, E. Selection of thermophilic and thermotolerant fungi for the production of cellulases and xylanases under solid-state fermentation. Braz J Microbiol, v. 43, n. 3, p. 1062-1071, 2012.

https://doi.org/10.1590/S1517-83822012000300032

OLIVEIRA, E. R.; MENDES, E. P. P. Setor sucroenergético e transformações espaciais em Frutal (MG). Espaço Ver, v. 16, n. 1, p. 33-50, 2014. https://doi.org/10.5151/9788580391091-V1_Cap13

PALMA-FERNANDEZ, E. R.; GOMES, E.; SILVA, R. Purification and characterization of two $\beta$ glucosidases from thermophilic fungus Thermoascus aurantiacus. Folia Microbiol, v. 47, n. 6, p. 685-690, 2002. https://doi.org/10.1007/BF02818672

PANDEY, A.; SOCCOL, C. R.; MITCHELL, D. New developments in solid-state fermentation: I-bioprocesses and products. Process Biochem, v. 35, n. 10, p. 1153-1169, 2000. https://doi.org/10.1016/S00329592(00)00152-7

PANDEY, A. Solid-state fermentation. Biochem Eng J, v. 13, n. 2, p. 81-84, 2003. https://doi.org/10.1016/S1369-703X(02)00121-3

PEI, X. Q.; YI, Z. L.; TANG, C. G.; WU, Z. L. Three amino acid changes contribute markedly to the thermostability of $\beta$-glucosidase BglC from Thermobifida fusca. Bioresour Technol, v. 102, n. 3, p. 33373342, 2011. https://doi.org/10.1016/j.biortech.2010.11.025

PEREIRA, J. C.; LEITE, R. S. R.; PRADO, H. F. A.; MARTINS, D. A. B.; GOMES, E.; DA SILVA, R. Production and characterization of $\beta$-glucosidase obtained by the solid-state cultivation of the thermophilic fungus Thermomucor indicae-seudaticae N31. Appl Biochem Biotechnol, v. 175, n. 2, p. 723-732, 2015. https://doi.org/10.1007/s12010-014-1332-1

PEREIRA, J. C.; MARQUES, N. P.; RODRIGUES, A.; DE OLIVEIRA, T. B.; BOSCOLO, M.; DA SILVA, R.; GOMES, E.; BOCCHINI MARTINS, D. A. Thermophilic fungi as new sources for production of cellulases and xylanases with potential use in sugarcane bagasse saccharification. J Appl Microbiol, v. v. 118, n. 4, p. 928-939, 2015. https://doi.org/10.1111/jam.12757 
RANI, V.; MOHANRAM, S.; TIWARI, R.; NAIN, L.; ARORA, A. Beta-glucosidase: key enzyme in determining efficiency of cellulase and biomass hydrolysis. Bioproces Biotech, v. 5, n. 197, p. 1-8, 2014.

SANTA-ROSA, P. S.; SOUZA, A. L.; ROQUE, R. A.; ANDRADE, E. V.; ASTOLFI-FILHO, F.; MOTA, A. J.; NUNES-SILVA, C. G. Production of thermostable $\beta$-glucosidase and CMCase by Penicillium sp. LMI01 isolated from the Amazon region. Electron J Biotechnol, v. 31, n. 1, p. 34-42, 2018.

https://doi.org/10.1016/j.ejbt.2017.11.005

SANTOS, F. A.; DE QUEIRÓZ, J. H.; COLODETTE, J. L.; FERNANDES, A. S.; GUIMARÃES, V. M.; REZENDE, S. T. Potencial da palha de cana-de-açúcar para produção de etanol. Quim Nova, v. 35, n. 5, p. 1004-1010, 2012. https://doi.org/10.1590/S0100-40422012000500025

SANTOS F. R. S.; GARCIA, N. F. L.; DA PAZ, M. F.; FONSECA, G. G.; LEITE, R. S. R. Production and characterization of $\beta$-glucosidase from Gongronella butleri by solid-state fermentation. Afr J Biotechnol, v. 15, n. 16, p. 633-641, 2016. https://doi.org/10.5897/AJB2015.15025

SHARMA, A.; TEWARI, R.; RANA, S. S.; SONI, R.; SONI, S. K. Cellulases: classification, methods of determination and industrial applications. Appl Biochem Biotechnol, v. 179, n. 8, p. 1346-1380, 2016. https://doi.org/10.1007/s12010-016-2070-3

SHI, Y.; XU, X.; ZHU, Y. Optimization of Verticillium lecanii spore production in solid-state fermentation on sugarcane bagasse. Appl Microbiol Biotechnol, v. 82, p. 921-927, 2009. https://doi.org/10.1007/s00253-009$1874-2$

SINGHANIA, R. R.; PATEL, A. K.; SUKUMARAN, R. K.; LARROCHE, C.; PANDEY, A. Role and significance of $\beta$-glucosidases in the hydrolysis of cellulose for bioethanol production. Bioresour Technol, $\mathrm{v}$. 127, n. 1, p. 500-507 , 2013. https://doi.org/10.1016/j.biortech.2012.09.012

VAN DEN BRINK, J.; DE VRIES, R. P. Fungal enzyme sets for plant polysaccharide degradation. Appl Microbiol Biotechnol, v. 91, n. 6, p. 1477-1492, 2011. https://doi.org/10.1007/s00253-011-3473-2

VAN DEN BRINK, J.; VAN MUISWINKEL, G. C. J.; THEELEN, B.; RINZ, S. W. A.; DE VRIES, R. P. Efficient plant biomass degradation by thermophilic fungus Myceliophthora heterothallica. Appl Environ Microbiol, v. 79, n. 4, p. 1316-1324, 2013. https://doi.org/10.1128/AEM.02865-12

YOON, L. W.; ANG, T. N.; NGOH, G. C.; CHUA, A. S. M. Fungal solid-state fermentation and various methods of enhancement in cellulase production. Biomass Bioenergy, v. 76, n. 1, 319-338, 2014.

https://doi.org/10.1016/j.biombioe.2014.05.013 